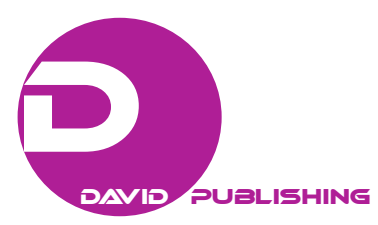

\title{
Banking and Financial Intermediaries: Overlapping Evolving Monetary Functions and Investment Fallouts
}

\author{
Mario Pines \\ University of Trieste, Trieste, Italy
}

\begin{abstract}
Since the New World Monetary Order, as designed and promoted at Bretton Woods, several policies were considered. As proposed by Hansen, Harrod, and post Keynesian, after the 60 years and after the Bretton Woods final collapse, a new monetary framework has been overlapping gradually most of the world financial transactions. Separately from the single global financial markets, without previous patterns and insight experiences, the new global landscape is posing new deep challenges in the present monetary stalemate. The removal of the gold benchmark on the first day of WWI (First World War)-The serious Gramm-Leach-Bliley Act 1999 repudiated the Glass-Steagall Act. The removal caused the colossal crisis as the time deposits and unlimited monetary base expansions produced effects never seen in modern history-A colossal surge of the financial instrument market indexes and financial bubble blowing erupted.
\end{abstract}

Keywords: monetary, multipliers, banking, intermediaries, market, prices, Central Banks' reserves

\section{Introduction}

\section{Monetary Debasement and Elements of Intermediation}

"Money will decide the fate of mankind, because individual liberty is only possible-or even thinkable - when confined within the boundaries of a collective discipline, calculated to curb the disorders that uncontrolled action is bound to provoke" (Rueff, 1964, p. IVX).

This sentence is to be connected to what Mundell said in his reconsideration of the 900 century monetary policies, formulated in his Nobel Prize ceremony message, in Stockholm in the year 1999 (Mundell, 1999).

One of the first questions arising in the Middle Ages first appearance of the deposit banks in the Florentine Renaissance was one single issue, the monetary function of the deposit banks. Further empowered by the Dutch Wisselbank, issuing bank's drafts, claimed by the city of Amsterdam, established in 1609, the precursor to, if not the first, modern Central Bank. In 1668, the Riksdag, Sweden's parliament, decided to found Riksens Ständers Bank (the Estates of the Realm Bank), which in 1867 received the name Sveriges Riksbank and started to refinance the commercial banks.

This question, related to the classification of banks' activities, is still pending now, and the solution leads to general macroeconomic wide and global consequences in a world with monetary masses expanding in uncontrollable quantities at the speed of light.

Mario Pines, professor, Department of Economics, Business, Mathematics, and Statistics (DEAMS), University of Trieste, Trieste, Italy.

Correspondence concerning this article should be addressed to Mario Pines, Department of Economics, Business, Mathematics, and Statistics (DEAMS), University of Trieste, Piazzale Europa 1, Trieste 34100, Italy. 
The question became relevant by the appearance of the Dutch Wisselbank in the 17th century. The Wisselbank was a bank issuing drafts and allowing gyro-accounts, and lately by the Riksbank in Stockholm introducing the fractional gold reserves monetary units, granting monetary credit and enabling monetary liabilities with purchasing power relying upon monetary deposits and bank credit, both progressively and partially surrogating legal tenderable currency bills.

Under fractional reserve banking, the flow of money instruments inverted its normal circuit: deposits started to stem mostly from the credit functions of both bank's deposits and credit, quantity multipliers. The leverage structure of the prevailing part of deposits and the monetary function of the bank' liabilities, turned upside down the classical bank image and representation and the monetary base became a smallest quantity.

There was a severance between intrinsic real value and monetary developments in a legal tenderable currency system: Instead of its intrinsic nature as money, the circulating monetary unit was better valued and understood trough the Fisher exchange formula and its dynamics:

The chief purpose of the foregoing chapters is to set forth the causes determining the purchasing power of money. This purchasing power has been studied as the effect of five, and only five, groups of causes. The five groups are money, deposits, their velocities of circulation, and the volume of trade. These and their effects, prices, we saw to be connected by an equation called the equation of exchange, $M V+M^{\prime} V=V Q$. (Fisher, 1911, p. 149)

The potential increase of money through Central Bank open market operations, is not negative by itself, if money is balanced by effective values acquired by the issuer; in the case of monetization of public debt, the problem lies with the "...way in which it is distributed" (Simmel, 1900; 2004, p. 172).

In the neoclassical framework, Gurley and Shaw, in the middle of the pseudo gold standard mechanism, retrieved in 1944 Bretton Woods, concluded that the rate of growth of money supply has neutral effects on the real variables in the economic world. They affirmed that there is no rational basis for choosing between alternative rates of growth of the money supply, as recollected since 1961 (Marty, 1961, pp. 56-62).

This question, related to the classification of bank activity and its regulation, is still pending, out of the Bretton Woods outcome and the answer leads to general macroeconomic, wide and global fallouts in a world with money circulating with the speed of light and swelling trough the bank multipliers to levels not under control, blowing multiple bubbles. Improperly, banks have been authorized to operate as financial intermediaries and this wording has never been removed even from commercial banks afflicted by non-performing loans due to irresponsible moral hazard, adverse selection of loanable parties and taxpayers as final shock absorbers of last resort.

The primary function of intermediaries is to issue debt of their own, indirect debt, in soliciting loanable funds from surplus spending units, and to allocate these loanable funds among deficit units. The rise of intermediaries-of institutional savers and investors-does not affect at all the basic equalities in a complete social accounting system between budgetary deficits and surpluses, purchase and sale of loanable funds or accumulation of financial assets and debt. (Gurley \& Shaw, 1955, p. 519)

The functions arise in the financial markets as considered by Gurley and Shaw themselves, according to a highly specialized formulation, indeed, the same authors used finally to define the function and types of intermediaries:

The principal function of financial intermediaries is to purchase primary securities from ultimate borrowers and to issue indirect debt for the portfolios of ultimate lenders. Although primary securities are their principal asset, financial 
intermediaries also hold the indirect debt of other intermediaries and own tangible assets as well. Financial intermediaries may be divided into two main groups: the monetary system and nonmonetary intermediaries. The monetary system, in its intermediary role, purchases primary securities and creates money. Nonmonetary intermediaries, in contrast perform only the intermediary role of purchasing primary securities and creating nonmonetary claims on themselves, which take the form of savings deposits, shares, equities, and other obligations. (Gurley \& Shaw, 1960, p. 192)

This strictly formal but relevant separation induces the same authors to articulate the finacial markets classification according to the specific group of intermediary, as agents or as investors, with deep alternative corollaries and fallouts.

The 15 August 1971 formal termination of the pseudo, or quasi gold standard, as reintroduced in the Bretton Woods disputed July 1944 agreements, leaves a singile currency as sole instrument of international liquidity, without a sound benchmark but an undisputable function, especially related to the oil revenues mostly denominated in dollars and deposited in London. The gold price, free to float on the global market, expressed the monetary related lost of purchasing power.

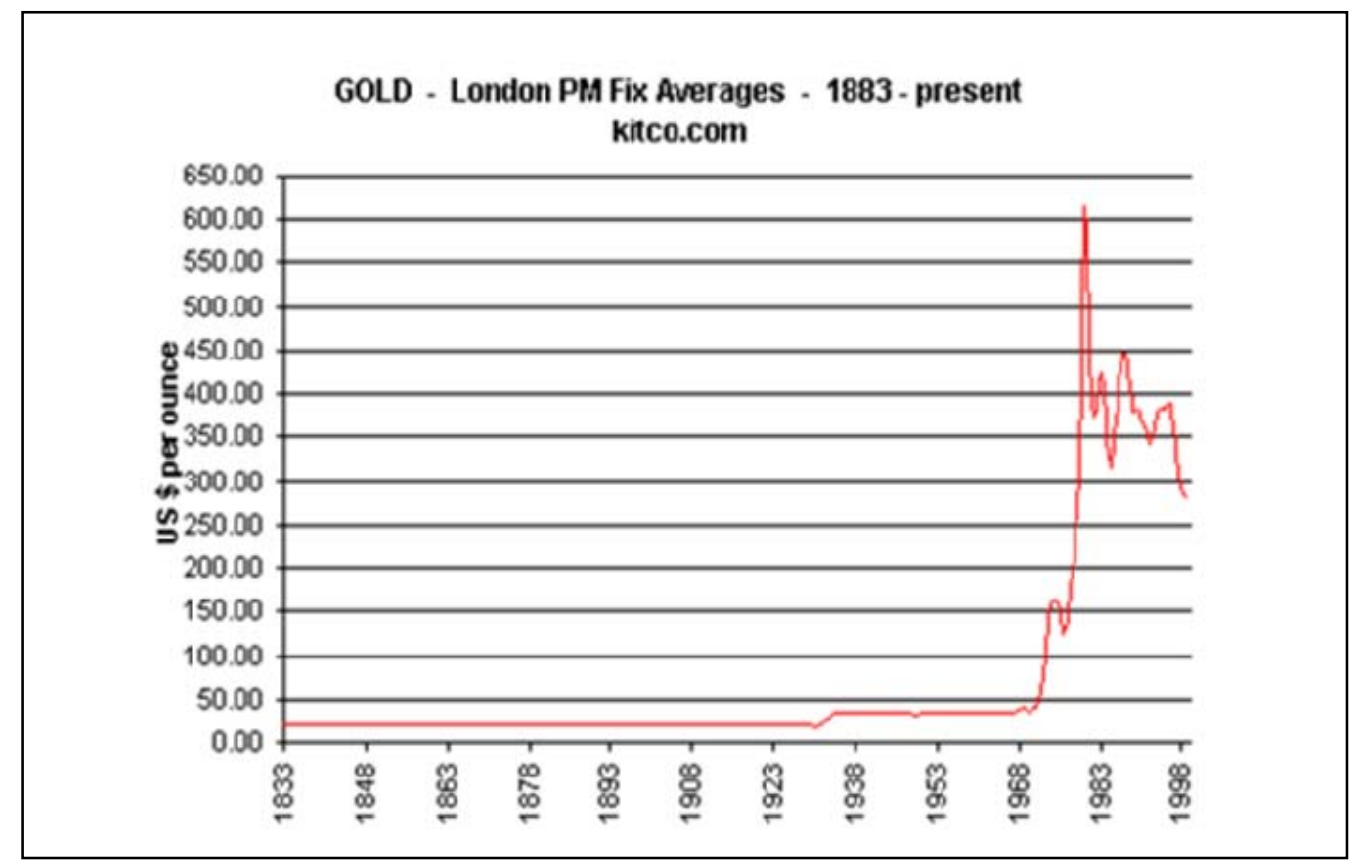

Figure 1. Gold price since August 1833.

Worse of all, the monetary quantity, after sone decades of different unsucesseful alternative experiments, from the SDR (Special Drawing Rights), to the ECU (European Monetari Unit), an finally to the EURO, EMS (European Monetary Sustem) agreements, after a stagflating decade, a bubble blowing high interest rates inflation recovery policy, erupted in 1987 in an endless monetary policy and dissolution of the interest rates balancing function, the system collapsed in an era of bursting bubbles, 1987, 1998, 2001, 2006, 2007, and 2008. The one way Abe-economics, deficit spending, and monetary policies as a standard global solution, left a growing percentage of the single uncovertible dollar as a last Noah's Arc on which all the other currencies, not able to support an international liquidity role, junped on to find a temporarily monetary solution to the growing World trade imbalances and growing internal deficits. Therefore, the prevailing reserve supporting the currencies issuance ended to be the dollar up to $67 \%$ in the 2 nd quarter 2017 . However, the dollar is not as solid as the 
Rock of Gibraltar, the greenback is part of a world monetary system that reflects a giant set of political unresolved conflicts and drawbacks. Given a choice, no one would design such a system. It is a big, rickety contraption held together with duct tape and glue. It is not pretty, but at present, it seems still intact.

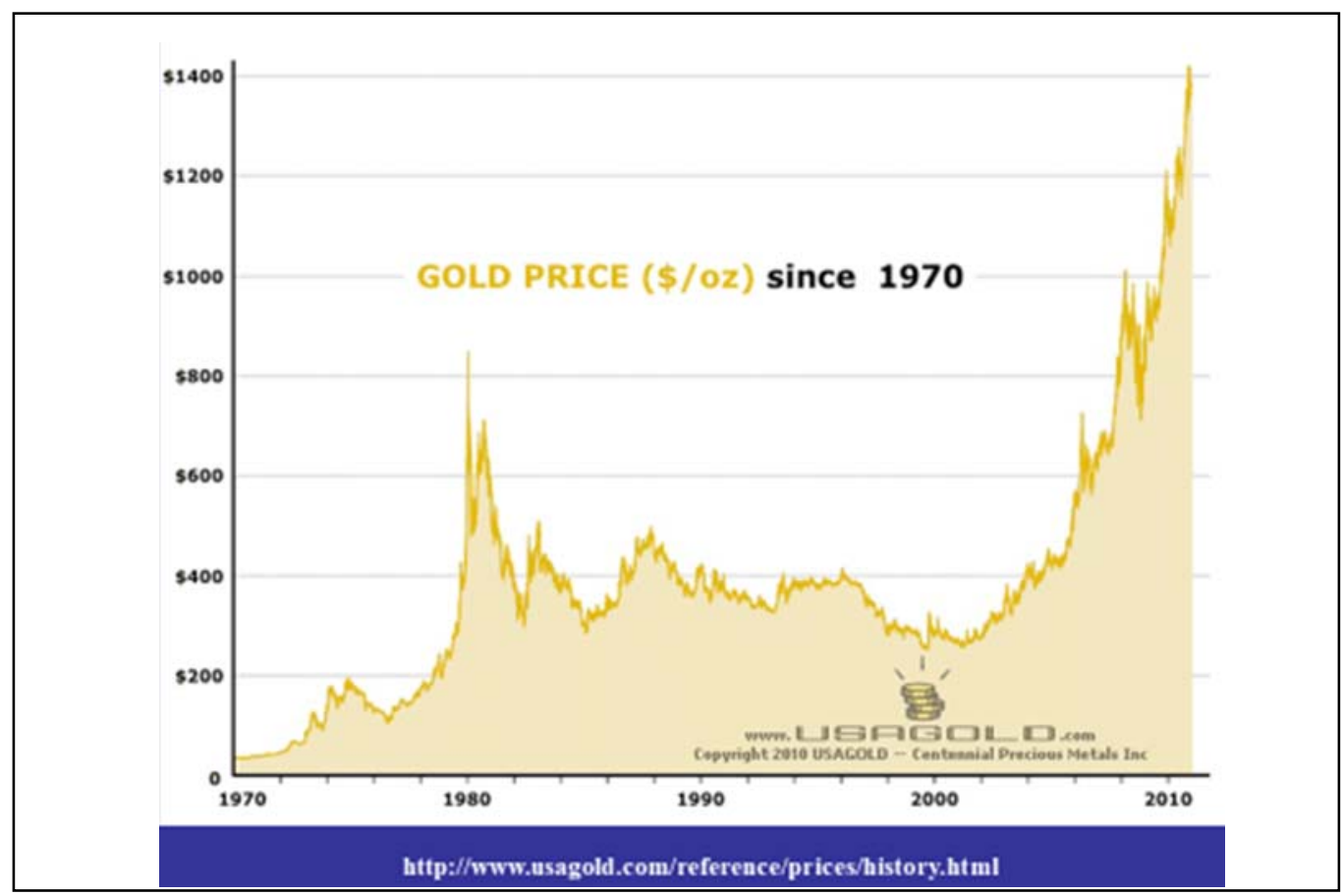

Figure 2. Gold price since the dollar debasement.

\section{Financial Profile of Chapters}

\begin{tabular}{ll}
\hline CHAPTER & FinanCial Markets \\
\hline II. & $\begin{array}{c}\text { Market for money only, with } \\
\text { emphasis on the demand for } \\
\text { money. }\end{array}$
\end{tabular}

III. Markets for moncy and for one type of primary security.

IV. Market for primary securities, with emphasis on growth in quantity and diversity of primary securities.

V. Markets for money and for differentiated primary securities:

VI. Markets for money, differentiated primary securities, and nonmonetary indirect assets.

Governmental monetary system composed of Policy Bureau and Banking Bureau.

Same as above.

Same as above.

Same as above.

Governmental monetary system and nonmonetary financial intermediaries (private and governmental).

VII. Same as above, with emphasis on supply function of money.

Central bank, member commercial banks, nonmonetary financial intermediaries.

Figure 3. Financial profiles. 
This very formal and scientific clear distinction between the different classes of very peculiar intermediaries suggest the same authors to propose an articulate deep analysis of different market's sections, according to differen operators, called financial intermediaries (Gurley \& Shaw, 1960, p. 6). The monetary function of nonmonetary intermediaries seems to prevail and intermediary's liablities, unconditionally, bear the largest size in the monetary circuits as happened with the subprimes' lending, based more on expected collateral value increases, instead of expectations of cash flows from actual operational income.

The habitual image of a bank has always been that of a safe depositary institution, not supposed to involve itself in any kind of general risks, taking care of peoples' savings, transferring monetary claims, and acting as a basic guarantor of deferred purchasing power for futures savers' necessities. The common public image, furthermore, was that of a supplier of temporary credit necessities of commercial and industrial firms, related to working capital flows, firms producing income under strict risk monitoring rules. These peoples' deeply rooted opinions stem from a real benchmark currency, with an intrinsic stable value, linked to the underlying asset's benchmarks, generally called money and as a bank's deposit money, instantly always at hand for any spending necessity.

The bank deposit account is actually an irregular deposit: The banks issues a liability, acquiring the property of the money deposited, in order to avoid any client's involvement in both the economic result and the risk of its operations going on with his monetary asset, always assumed liquid, and promptly at hand, in case of a necessity.

After the irregular deposit, the bank is holding the full property of the money deposited and its actual readiness to satisfy its clients' requests is bound to the performance of the assets acquired appearing in its financials assets section.

The trust contract, on the contrary, according to the running juridical structure of general legislative frameworks, implies both a transfer of the property and all titles linked to the money trusted, to a third party. This is the very different case of the nonmonetary intermediary operations. A management agreement usually completes the scheme, where the principal empowers the trustee with investment strict guidelines, binding the bank or financial institution. Managing others people money from both a legal property point of view and a responsibility and risk sharing perspective, is the essence of a trust contract that never may affects or relates to a monetary intermediary like a commercial bank.

In the market economy, recurring cyclical fluctuations are generally due to the following hypotheses:

- factual concrete events, like the Californian earthquake that struck the coast of Northern California at 5:12 a.m. on April 18, 1906 and ignited a howling blaze that threatened total destruction of the city, or the strike against the two towers at the World Trade center on September 11, 2001. Otherwise, a constant pattern of planned investments without a riskless return, as capital and interests required to meet the amortization schedule in a sound loan, or in a covered hedge function, never leads to fluctuations, more easily connected to;

- propriety trading speculative assets, linked to the uncertain perspective of true optimistic managing investors, wrongly relying on future profits;

- credit allowed on a Ponzi scheme of roll over liabilities, in a growing intricate network that leads to the fatal financial fluctuations, when widely extended over a too gross layer of unproductive initiatives in a NPO (Not Performing Loans) final dead way condition.

With the first gold debasement, on July 31, 1914, due to the colossal equities sales orders coming from all over the world, in order to redeem the equivalent gold reserves from the issuing American banks started the new fiat money epoch and a four months closure of the NYE. The banking system was manifestly unable to 
fully satisfy such requests in a regime of fractional reserves banking. The attempts to regain the gold convertibility were evident during the two World Wars aftermaths following efforts. The final weak pseudo convertibility, created and enacted by Harry Dexter White in Bretton Woods in July 1944, proposed the IMF (International Monetary Fund), the World Bank, and the GATT (General Agreement on Tariffs and Trade), new institutions guidelines. The international imbalance restoration was considered impossible, by two economists: the British Robert Triffin (1961) and the French Jacques Rueff (1971). Notwithstanding, the pillars of the new reestablished financial order in the Western world, most economies have fallen into a confused new era of stagflation, financial instability, bursting bubbles and monetary policies, with interest rates close to zero and in many cases even below zero. Finally, it was also tested and verified that, in a global economy, the Phillips and Taylor interest rates and employment curves are not able to explain and compose instable economy disequilibrium, both internal and external.

\section{Consequences}

After the three basic changes in the structure of the banking activity: Initially a depositary of means of payment, the new depositary functions, through irregular deposits and secondly, the issuance of liabilities, alternative to the legally or sound tenderable money. This profile became the rule in a fiat money system with Central Banks. At same time, as third step came the credit function, provided by banks, when conceding loans. This became the basic industrial revolution financial source and put the banks at the center of the financial market; initially as commercial banking sections of the financial market, discounting sound credits in the distribution area of firms with delayed revenues, or supplying working capital under the real bill doctrine.

In the sequent evolving years, the commercial banks became depositary institutions of savings and management trusts for entities with temporary excessive cash at hand. In any case, the title to the assets has always been transferred to the bank in an irregular type of deposit ${ }^{1}$, becoming liabilities towards clients and as such entered in the bank' accounting system of formal debts, even if a pro tempore transfer of fungible property were running.

This plane set of relations requires the bank to run all the risks related to assets with corresponding liabilities, as much cautiously as possible. The clients always rely on their undisputable right of using their bank assets as currency, to meet their payment necessities trough any short of alternative circulating instruments, from drafts to bank orders, to checks to electronic transfer messages.

In order to substantiate this belief and actual capability, after the Great Panic of the 1907, on the 22 December 1913, both houses of Congress passed the Federal Reserve Act. Wilson signed it into law immediately. The act title was "An act to provide for the establishment of Federal Reserve Bank, to furnish an elastic currency, to effort means of rediscounting commercial paper, to establish a more effective supervision of banking...". After the roaring 20 years, without a gold restrain, in the booming stock exchange monetary growing indexes till the 1929 October crash, out of the gold standard, the Congress in the year 1933 passed the basic Glass and Steagall Act, regulations covering a raft of ills, fearing that a money trust was at the heart of market abuses. Under the Glass and Steagall Act, financial institutions were no longer allowed to take deposits

\footnotetext{
${ }^{1}$ A law dictionary, adapted to the constitution and laws of the United States. By John Bouvier. S.V. "Irregular deposit". Retrieved January 212018 from https://legal-dictionary.thefreedictionary.com/Irregular+deposit.
} 
and underwrite securities offering, if not under a formal strict trust account under a fiduciary trust account ${ }^{2}$.

Considering the small amount of legal tenderable residual currency in circulation, in the form of M0 (monetary base), statistically decreasing, less than $10 \%$ of total monetary banks' deposits, we can assume indisputable that most of the bank deposits, M1, M2, and the residual M3, at system level come as fallout from the credit originated by banks to third parties. The need of financial liquid assets, in a leveraging process, where credit precedes new deposits, generally a fallout of the banking credit activity itself, and the system's liquidity are the result of credit in a self-propelling process called leverage.

This premise related to the banking system globally considered, presumes the credit originates the deposits' growth, on the contrary of what looks in the single bank, where the credit utilized by the clients in first instance falls back on the same or some other bank of the system as deposit of the beneficiary. From a systematic point of view, therefore, credit creates deposits and the fact from a single bank point of view is always the opposite since banks lend what they receive from savers or liquid asset holder, clients holding assets received after the lending process of other banks of the system.

The potential spending monetary system's mass therefore, only in a very limited quantity is originated by the issuing banks as legal tender bills. It is called therefore monetary base, most of the paying instruments come instead from the banks' lending activity, a self-sustaining process without limits, as long as there is a demand of credit in the production sector and a monetary function of the commercial banks liabilities.

According to the first close analyst of the instability hypothesis (Minsky, 1992), after a long period of recurring monetary turbulences, the Keynes theories about the credit cycles and the government intervention trough the monetary policies, seem to adhere to a close observation in both monetary gold standard and fiat money standard. If we compare the first major 1907 USA banking panic, faced with the Aldrich-Vreeland Act passed on May 27, 1908 enacting emergency currency issuance and the 1931-1933 deep bank holyday insolvencies, the first lies in natural events and partially on the trust banking activity failures. In the second case, the WWI (First World War) gold standard collapsed, with the emergency monetary issuance and the contextual closure of the New York stock exchange on 1 August 1914; the emergency monetary issues seem to have avoided a major economic depression also in this occurrence. The 1933-second depression really has no new Deal solution, both employment and exchange indexes never regained their previous level before the year 1954, after the WWII. Both recoveries come out of the fair public spending in new monetary denominations and values.

The modern crises, coming out of the gold parities dismissal, both real and pseudo or quasi, start definitively on 15 August 1971 with the Nixon statement about the temporarily gold conversion holdup.

After August 1971, a slow monetary erosion starts to confuse economists all over the Academia from unorthodox monetarists to Keynesians, from the gold base, to the bitcoin. The banking industry reforms seem contradictory, confused since the New Deal's strict separation between banking commercial orthodox functions, to the Gramm-Leach-Bliley Act, a Clinton's Act of 1999 reform, inserting again the trust or the proprietary investment banking in an undecided shoreline between trust and banking activities. So, for an interrupted row of collapses of classical acquired values in the ethical consumer protection, to general wide panicking landscapes, trough monetary bubbles inflated by the irresponsible deficit spending, often used to acquire electoral populism consensus.

\footnotetext{
2 Trust account, business Dictionary.com, WebFinance, Inc. Retrieved from http://www.businessdictionary.com/definition/ trust-account.html (accessed: January 17, 2018).
} 


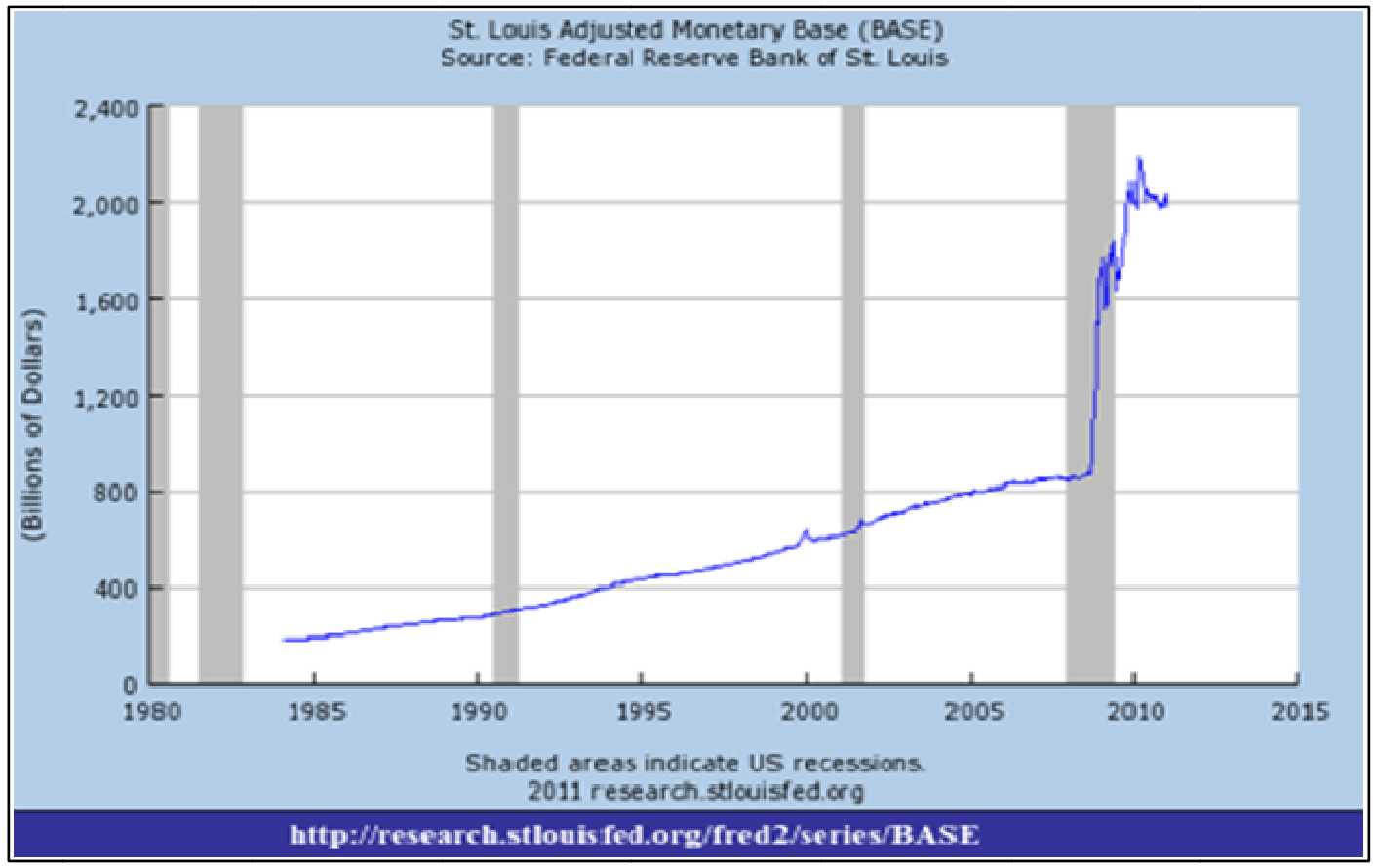

Figure 4. Monetary basis expansion in rescuing non-performing loans.

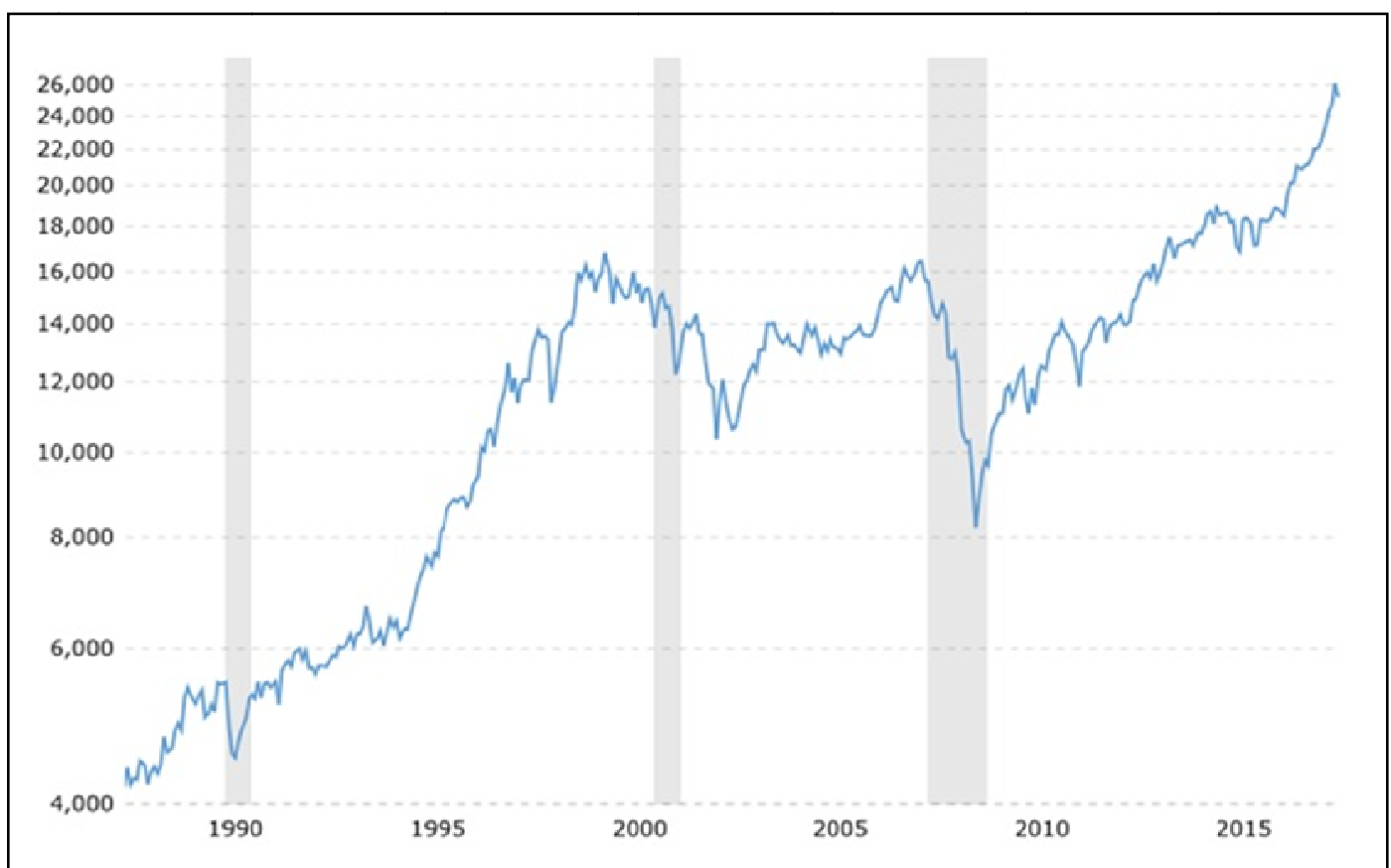

Figure 5. Dow Jones 1987-2015 (see http://www.macrotrends.net/1319/dow-jones-100-year-historical-chart).

\section{Perspectives}

According to this Keynes "veil of money", the scope of countercyclical economic policy is radically curtailed in the new classical macroeconomics. In the case of rational probabilities, the monetary authority is not able to carry out systematic countercyclical economic policy, that is, it cannot exploit the existing short-run Phillips curve; it is different from the Quantity Theory of Money "veil of money". The Quantity Theory "veil of money" has the trading exchanges in commodity markets are of goods for money and money for goods; 
therefore, the exchanges are really of goods for goods. The Keynes veil implies that money reflects constantly financing terms through time. We can structure a part of the financing in the economy as dated payment commitments, in which banks are the central player. The money flows are first from depositors to banks and from banks to firms; then, later, from firms to banks and from banks to their depositors. Actually, in an almost banking monetary function system, all these processes are inversely running in real terms, the monetary base is the single quantity reflecting the third parties originate monetary flux, the remnant is pure bank leveraging trough the multiplier effect due to the fractional reserve lending capabilities. Initially, the exchanges are for the financing of investment, and subsequently, the exchanges fulfill the prior commitments, which are in the financing contract as original covenants.

In a Keynes "veil of money" world, the flow of money to firms is a response to expectations of future profits, and the flow of money from firms is self-financed by net profits that are realized. In the Keynes set up, the key economic exchanges take place because of negotiations between generic bankers and generic executives. The documents "on the table" in such negotiations detail the costs and profit expectations of the businesspersons, who interpret the numbers and the expectations as enthusiasts, bankers as skeptics.

Thus, in a capitalist economy the past, the present, and the future are linked not only by capital assets and labor force characteristics, but also by financial relations, the so-called IS-LM model, also known as the "Hicks-Hansen synthesis". The IS-LM diagram claims to show the relationship between the investment-saving (IS) curve and the liquidity preference-money supply (LM) curve. The key financial relationship links the creation and the ownership of capital assets to the structure of financial relations and changes in this structure. Institutional complexity may result in several layers of intermediation between the ultimate owners of the communities' wealth and the units that control and operate the communities' wealth trough the leverage monetary multipliers. This perspective falls with the globalization of fiat money, unlimited potential supply of liquidity based by the legal tender alone as envisaged by Hansen (Hansen, 1953) but actually provided by the huge deficit spending, stemming out of Camp David August 1971 Nixon temporarily prophecy.

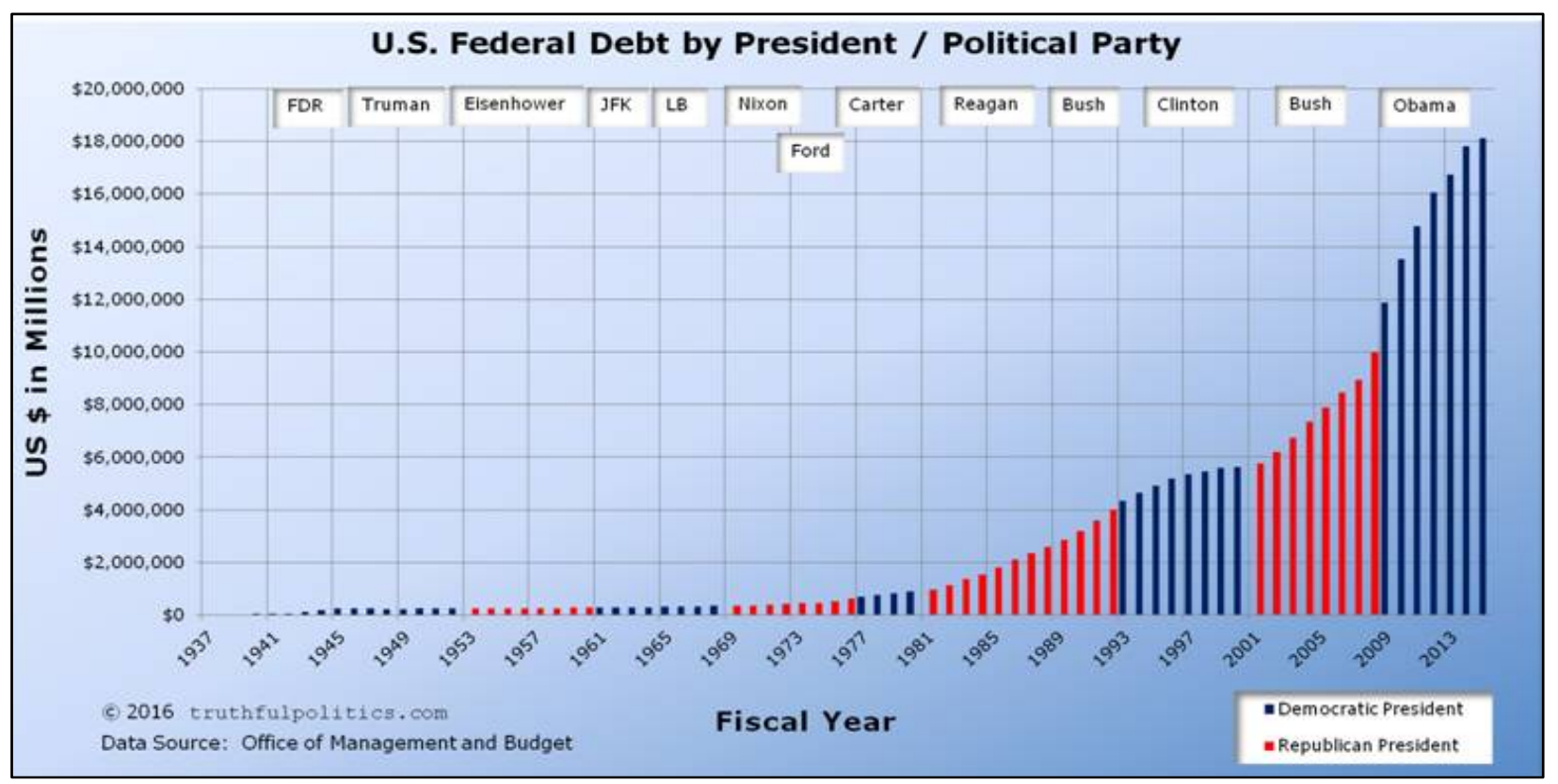

Figure 6. Federal debt growth in the years 1937-2015. 
Expectations of business profits drive both the flow of financing contracts to business and the market price of existing financing contracts, therefore a financial inflation. Profit realizations determine whether the commitments in financial contracts are met, whether financial assets perform as the pro-forma indicated by the negotiations, whether finally there is enough quantity of idle money balances.

In the modern world, analyses of financial relations and their implications for system behavior cannot be restricted to the liability structure of businesses and the cash flows they entail. Households (by the way of their ability to borrow on credit cards for big ticket consumer) goods, such as automobiles, house purchases, and to carry financial assets, governments (with their large floating and funded debts) and international units (as a result of the internationalization of finance) have liabilities structures which the current performance of the economy either validates or invalidates.

An increasing complexity of the firms' financial structure, in connection with a greater involvement of governments as refinancing agents for financial institutions as well as ordinary business firms (both of which are marked characteristics of the modern world), may make the system behave differently than in earlier eras. In particular, the much greater participation of national governments in assuring that finance does not degenerate as in the 1929-1933 period, means that the down side vulnerability of aggregate profit flows has been much diminished. However, the same interventions may well induce a greater potential degree of upside (i.e., inflationary) bias to the economy.

In spite of the greater complexity of financial relations, the key determinant of system behavior remains the level of profits. The financial instability hypothesis incorporates the view of profits (Kalecky, 1965; Levy \& David, 1983), in which the structure of aggregate demand determines profits. In the skeletal model, with highly simplified consumption behavior by receivers of profit incomes and wages, in each period aggregate profits equal aggregate investment. In a more complex (though still highly abstract) structure, aggregate profits match aggregate investment, plus the government deficit. Expectations of profits depend upon investment in the future, and realized profits are governed by investment; thus, whether or not liabilities are justified depends upon investment. Investment takes place now because businesspersons and their loaded bankers expect investment to take place in the future.

The financial instability hypothesis, therefore, is a theory of the impact of debt on system reactions and incorporates the manner in which debt is provided. In contrast to the orthodox Quantity Theory of money, the financial instability hypothesis takes banking seriously as a profit-seeking operator. Banks seek profits by financing activity and investment bankers. Like all entrepreneurs in a capitalist economy, bankers are aware that innovation assures profits. Thus, bankers (using the term generically for all intermediaries in finance, monetary and nonmonetary after the Financial Modernization Act), whether they be brokers or dealers, are merchants of debt who strive to innovate in the assets they acquire and the liabilities they sell. This innovative characteristic of banking and finance invalidates the fundamental presupposition of the orthodox Quantity Theory of money. There is an unchanging money growth item, out of the monetary function of non-banking intermediaries as well, whose flow is sufficiently close to being constant: hence, changes in this money's supply have a linear proportional relation to a current adverse choice theory in a full moral hazard hypothesis, with credit price level lately close to zero.

Three distinct income-debt relations for economic units, which are labeled as hedge, speculative, and Ponzi finance, can be identified and develop (Minsky, 1992, p. 7). 


\section{Trust Intermediaries}

An investment bank is a nonmonetary financial intermediary that performs a variety of different services. Investment banks specialize in large and complex financial transactions, such as underwriting, acting as an intermediary between a securities issuer and the investing public, facilitating mergers and other corporate reorganizations, and acting as a broker and or financial adviser, generally for institutional clients.

Major investment banks included Barclays, BofA Merrill Lynch, Warburgs, Goldman Sachs, Deutsche Bank, Morgan, Morgan Stanley, Salomon Brothers, BS, Credit Suisse, Citibank and Lazard, Lehman Brothers. Some investment banks specialized in particular industry sectors. Many investment banks also had monetary intermediation retail operations that serve small, individual customers outside of a principal trustee contract at same time, within the Financial Modernization 1999 Act.

The advisory divisions of investment banks apply a fee for their services, while the trading divisions experience profit or loss based on their market performance on other people's money. Professionals who work for investment banks may have careers as financial advisers, traders, or salespeople. An investment banker career could have been very lucrative, but it typically came with long hours and significant stress and relative regard about others people's money. The bank, as a depositary institution, typically a commercial bank is normally an evolving firm that has a main function: the custody of monetary values underlying the fiat money scheme, generally an intrinsic quality of the instrument itself.

The three stages of the modern banking activity start from the Italian middle ages Florentine banks, as sometimes hindered in their evolution from the defaults of their main clients like King Edwards III of England and King Robert of Naples. Other times capable to imprint an age as the Medici left on the Renaissance, as depicted by Niccolò Machiavelli, in the area of commercial banking and issuing bills of exchange and further financing trade in the course of the Middle Ages. The Northern European Nations adopted the Florentine model but further implemented the circulation of multiple currencies, the pioneering of the checks and direct debiting and crediting; starting the gyro-account bank activities of scriptural currency transforming the bank debit in actual agreed currency. The first bank trying this new paying technology and exchange activities was the Wisselbank (Amsterdam Exchange Bank) in the year 1609 in an area with 14 different mints and copious quantities of foreign currencies.

In Stockholm, the foundation of the Stockholm Banco, the Riksbank was also designed to be a Lanebank, meaning that it engaged in lending as well as facilitating commercial payments. By lending amounts in excess of its metallic reserve, it had pioneered the practice of what would later become the fractional reserve banking, profitably lending money left on deposit as well as facilitating commercial payments.

The third step in banks' activity evolution comes in 1694 with the establishment of the Bank of England, aimed to assist the government's debt endorsed with distinctive privileges. Firstly, it was allowed to operate a partial monopoly on the issue of banknotes, a distinctive form of promissory notes that did not bear interest and allowed to perform transactions without current accounts.

\section{Conclusions}

The scenario on the international arena seems not to be much far since the one seen in 1944 in Bretton Woods, and the proof of the stalemate is the recurring presence of the IMF, the World Bank and the WTO (World Trade Organization) to try to absorb the locally instabilities and avoid spread panics in the banking sectors. 
The debased currency has two unavoidable bad fallout effects, first the fiat money is a temporary instrument of payment or monetary exchanges in the short time market, it is not likely to permit any delaying expenses or saving functions as performed under both the gold or silver standards and lately the oil standard. Furthermore, it is short time financial transaction instrument, which allows and causes a market irrational exuberance. That is a financial instrument potentially inflation device, which have proved several times in the history the bubbles emotion, and the consequent spread wide banking panicking, as a fallout effect as well. The problem was seriously faced in the thirties trough the credit separation. The Glass and Steagall Act, signed by President Roosevelt, that was actually the result of the November 1910 Jekyll Island Georgia, private bankers proposition, guided by J. P. Morgan, to activate a public clearing function and “...produced a design of a National Reserve Bank...Ironically, the Fed, one of the money trust that the Progressive feared, though President Woodrow Wilson, Treasury Secretary Carter Glass, and Democrats would later claim the credit for establishing the Fed" (Bruner \& Carr, 2007, p. 145) which was at the base of the 1913 FED system activation.

The irregular juridical profile of the commercial banking activity, strictly separate from the trust or banking activity, whose joined activities may be confused in an intermediary function linked formally and legally to a management relationship. A formal mandate contract with the interposition of a principal and a trustee in a management account not to be considered as a liability of the agent. The positioning of the commercial banking activity within the intermediary hypothesis leads to a false concept of the banking activity itself overlapping financial instruments in the proper financial markets.

The full evidence of such a confused management hypothesis came out of the 1999 repudiation of the Glass and Steagall Act, signed by President Clinton under the proposal of Gramm-Leach-Bliley, Senators that de facto reintroduced the commercial-investment banking activity. The circumstance led to the dot.com, sub-prime, and derivatives bubbles, that were temporarily allocated Worldwide in negotiable financial instruments that, together with the gold pool were stock piled to inflate the huge internal public debt after the special TARP (Troubled Asset Relief Program) and all short of similar EBC (European Central Bank) financial devices under a same prospective. The scope was to bailout over the contributors the losses linked to the improper management of the financial and industrial collapses in a concurring adverse selection and questionable moral hazard, at rate close to zero, an uncertain prospective for monetary savings, but only way out to absorb the liquidity and financial general shocks prospective.

This merchant, investment, trust-banking activities should never miss a specific client mandate and sole risking person to whom both profits and losses can be assigned. In a plane banking commercial relationship, the bank acquires the property of a fungible asset that becomes a liability to the client to be fully and constantly available as the transfer of this client credit allows the monetary function of commercial banks. Nonmonetary financial intermediaries cannot operate such role in any circumstance, as agents between the trusting creditor and the potential beneficiary.

The inclusion of huge amount of public debt within the Central bank's assets, to supply liquidity to the instable banking sector, is the main origin of leveraging. The sector had been increasing corresponding credit towards the state involved in restructuring processes, but has supplied monetary base M0 in a process of leveraging banking quantities, credit and as a fallout liabilities in a bubble spiral reaching first-time index values on financial markets, not reflecting actual parallel economic growth. The international monetary arrangement between the opposite Robert Triffin and Jacques Rueff visions of the impossible balance appears inserted in Harry Dexter White 96 pages agreement, as signed in July 1944 (Triffin, 1961; Rueff, 1964). 

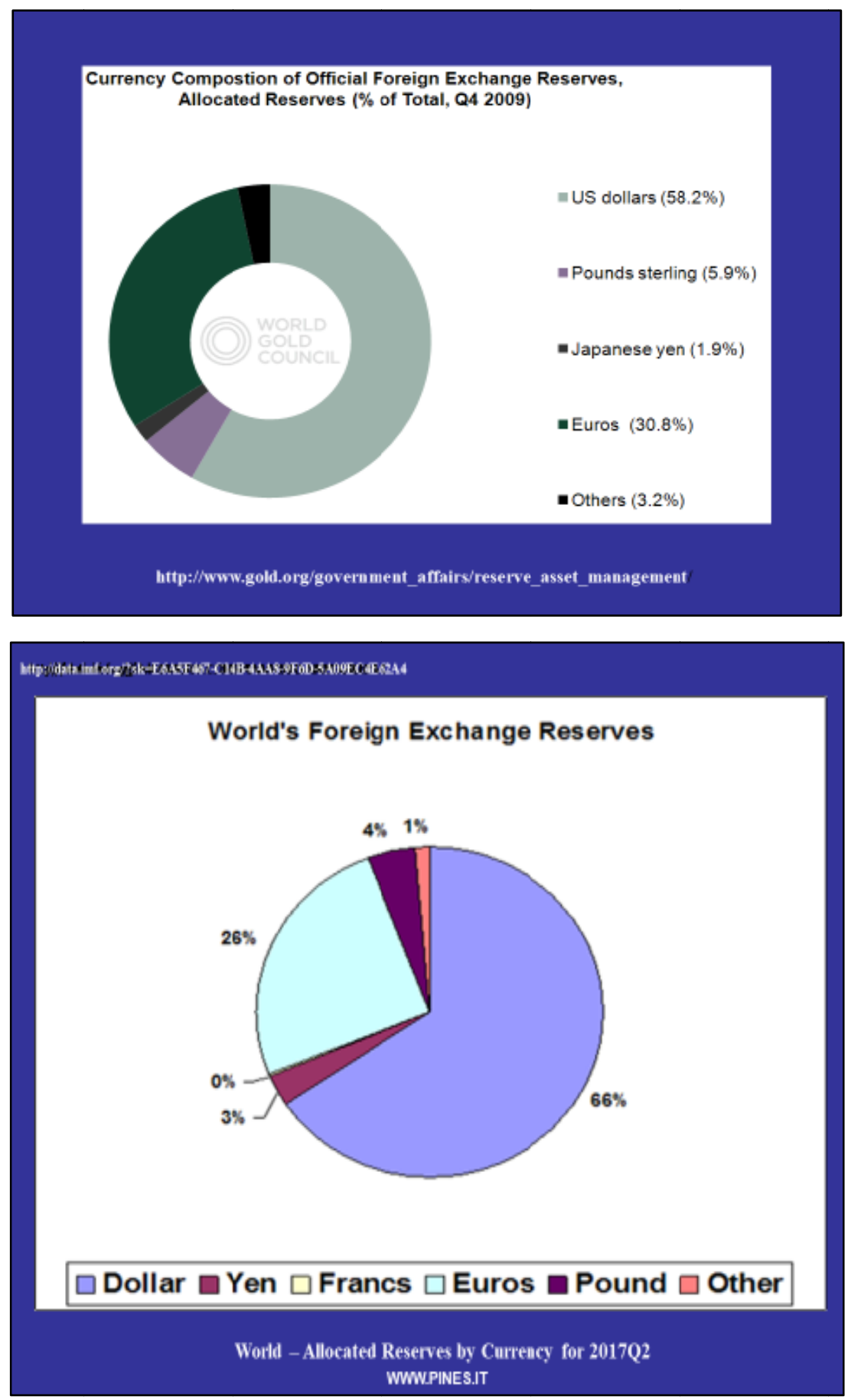

Figure 7. Central banks reserves.

The basic critic to the Bretton Woods, called Triffin dilemma (Triffin, 1961) was first in predicting a diverging gold base for a growing dollar monetary expansion, and an unrecoverable imbalance among international trade deficits. Furthermore, the surpluses would end without any automatic chance to restore a compensating price adjustment, as happened within the Hume gold exchange standard self-regulating mechanism. The three remedies adopted in Bretton Woods: the IMF interventions, the World Bank 
restructuring financing projects and the WTO ex GATT trade clauses, are not solution presently efficient to reestablish some kind of equilibrium, as has happened in most of South American Countries and even in developed nations, not able to trust in new trade equilibriums.

On the other side, the monetary functions are performed by non-banking financial intermediaries and the banking role of the trust operations, without a clear-cut distinction between investment banks and commercial banks, the Demons of our own design (Bookstaber, 2007) have become actual consequences of the presumed financial innovation. It has become evident once more that after 50 years of efforts we have not resolved the debasement of the world currencies emptiness and sudden volatile foreign exchanges, direct as gold standards, indirect as quasi gold standard which have not been yet restored and the Noah's Arc only remaining currency has become doomed without solutions at hand.

The infringement of the borderline between the commercial and the investment banking has produced a powerful self-inflating huge monetary bubble, engulfed by the monetary policies of Central Banks. The unlimited debt bubbles both public as deficit spending and as well as private trough too large to fail theory and the recovery monetary programs within the social pressures and the crony monetary solutions to related problems, mostly aggravated by the Far East competition and the false financial indexes misrepresenting huge surge trough the exchange indexes.

The actual perspective, from a monetary point of view is very complex and leaves very little room to a likely short time solution to the international imbalances in a newly globalized World. Money in a theory of finance, as understood and clearly explained by Gurley in his study paper:

Close substitutes for money include time deposits in commercial banks, savings, and loan shares, mutual savings deposits, shares and deposits in credit unions, deposits in the Postal Savings System, policy reserves in private life insurance companies, and US Government savings bonds. There is, however, no hard and fast line between these financial assets and some others. (Gurley, 1960, p. 4)

The clear-cut money offer structure is linked to the global supply of legally tenderable money and quasi money under this precise Gurley's definition. The absence of a monetary instrument with a sound and reliable benchmark has two historic precedents, the gold standard and the oil standard, being oil the universal accessible lasting substance capable of saving, trading and easily convertible in currency universally therefore accepted. Nowadays, in the perspective of electric motion and shale substitute oil, gold has lost most of its appeal, and for the FED (The Federal Reserve Bank, USA), it will be a hard task to roll over indefinitely its colossal external debt denominated in dollars.

As long as nothing comes on the horizon as a valid substitute, the synthetic currencies, both as multilateral convention lake the SDR or the ECU are not likely to substitute a structural material benchmark, nor a single country liability could hold a worldwide demand of international liquidity.

The growing mole of payment instruments will just blow bubbles without allowing a wise and necessary saving function in order to supply working capital to existing industrial structures and to allow the economic capital formation for new enterprises. From a USA point of view, the Full Employment Act created the Council of Economic Advisors that has been swindling between the supply side approaches up to the 21 trillion current deficit spending (FED Act, Section 13, point 3). 
Table 1

Global Imbalance, Internal, and External Deficits in US\$ per 2 Q 2017

\begin{tabular}{|c|c|c|c|c|c|}
\hline Country & Public debt & External debt & GDP & $\begin{array}{l}\text { External debt } \\
\text { /GDP }\end{array}$ & $\begin{array}{l}\text { Public debt } \\
\text { /GDP }\end{array}$ \\
\hline USA & $20,608,244,255,690$ & $19,274,778,642,369$ & $19,651,097,152,846$ & 0.98085 & 1.04871 \\
\hline China & $2,234,221,651,151$ & $1,566,874,156,596$ & $11,257,897,374,596$ & 0.13918 & 0.19846 \\
\hline Japan & $12,197,370,093,649$ & $4,034,140,973,932$ & $4,945,133,459,918$ & 0.81578 & 2.46654 \\
\hline Germany & $2,273,910,941,565$ & $5,558,238,207,248$ & $3,481,514,692,921$ & 1.5965 & 0.65314 \\
\hline UK & $2,447,269,514,237$ & $7,078,976,647,543$ & $2,630,807,435,537$ & 2.6908 & 0.93024 \\
\hline France & $2,507,135,062,469$ & $5,569,101,039,779$ & $2,467,807,435,538$ & 2.2567 & 1.01594 \\
\hline India & $1,229,046,988,741$ & $409,609,428,548$ & $2,269,933,103,617$ & 0.18045 & 0.54145 \\
\hline Italy & $2,510,776,395,873$ & $2,719,301,869,506$ & $1,851,628,673,230$ & 1.4686 & 1.35598 \\
\hline Brazil & $1,337,443,155,133$ & $573,116,414,222$ & $1,796,603,179,380$ & 0.319 & 0.74443 \\
\hline Canada & $1,524,995,239,334$ & $1,726,182,545,418$ & $1,530,982,301,923$ & 1.1275 & 0.99609 \\
\hline Argentina & $292,174,187,161$ & $251,918,045,329$ & $544,334,583,685$ & 0.4628 & 0.53675 \\
\hline Australia & $676,899,091,364$ & $1,565,962,711,633$ & $1,263,178,762,308$ & 1.2397 & 0.53587 \\
\hline Belgium & $509,000,345,629$ & $1,416,923,093,545$ & $466,937,911,862$ & 3.0345 & 1.09008 \\
\hline Greece & $356,221,168,251$ & $584,882,109,232$ & $194,603,929,207$ & 3.0055 & 1.83049 \\
\hline Indonesia & $360,915,764,696$ & $331,935,605,365$ & $934,187,789,500$ & 0.35532 & 0.38634 \\
\hline Ireland & $219,262,849,454$ & $2,714,247,776,790$ & $304,985,367,521$ & 8.8996 & 0.71893 \\
\hline Korea & $675,952,814,683$ & $322,796,998,691$ & $1,412,492,883,608$ & 0.22853 & 0.47855 \\
\hline Mexico & $610,662,832,623$ & $500,151,695,406$ & $1,047,942,873,857$ & 0.47727 & 0.58273 \\
\hline Netherlands & $459,388,385,649$ & $4,078,586,110,588$ & $778,148,225,777$ & 5.2414 & 0.59036 \\
\hline Nigeria & $79,572,729,521$ & $36,211,881,773$ & $405,140,709,689$ & 0.089381 & 0.19641 \\
\hline Norway & $162,616,561,067$ & $161,928,734,852$ & $370,741,431,079$ & 0.43677 & 0.43863 \\
\hline Poland & $258,267,236,345$ & $383,271,935,265$ & $469,115,353,870$ & 0.81701 & 0.55054 \\
\hline Portugal & $280,531,770,404$ & $453,777,606,774$ & $204,717,859,232$ & 2.2166 & 1.37033 \\
\hline Russia & $152,404,365,374$ & $368,190,669,707$ & $1,283,117,859,232$ & 0.28695 & 0.11878 \\
\hline Saudi Arabia & $250,873,831,278$ & $224,665,092,471$ & $658,455,722,364$ & 0.3412 & 0.38100 \\
\hline Spain & $1,294,917,345,099$ & $2,360,919,321,939$ & $1,234,532,170,016$ & 1.9124 & 1.04891 \\
\hline Sweden & $204,485,289,919$ & $960,429,175,204$ & $511,628,582,572$ & 1.8772 & 0.39968 \\
\hline Switzerland & $213,309,834,080$ & $1,666,021,054,888$ & $669,353,577,697$ & 2.489 & 0.31868 \\
\hline Taiwan & $176,509,180,270$ & $198,621,883,513$ & $529,898,576,722$ & 0.37483 & 0.33310 \\
\hline Turkey & $275,024,385,846$ & $419,449,642,271$ & $864,060,733,090$ & 0.48544 & 0.31829 \\
\hline Total & $56,379,403,266,555$ & $67,511,211,070,395$ & $66,030,979,712,394$ & & \\
\hline
\end{tabular}

Source: http: //www.usdebtclock.org/world-debt-clock.html, date 01/15, 2018.

The result has become currently the last World economy issue, the huge present monetary expansion, the leveraged Central Banks and the everlasting deflation. We can understand it, considering the financial markets price indexes explosion and the balancing decreasing industrial Asian Countries prices. These details allow a huge compensating deflating factor. The process is reliable as long as the external imbalances are supporting the internal deficits on a free choice basis or compulsory in the financial markets, under pressure of the monetary reserves suppliers (FED and BCE) which count over $92 \%$ of total Central Banks' reserves. The temporarily alternatives shows that there is no solution and that floating rates and new legal tenderable currencies, will not ever be able to reestablish a global Central Banks' reserves structures. Satisfying solution will not easily be ad hand unless a new currency has a benchmark and is not available to local monetary policies based on irretrievable deficit spending. 


\section{References}

Bookstaber, R. (2007). A demon of our own design. Hoboken, NJ: Wiley and Sons.

Bruner, R. F., \& Carr, D. S. (2007). The panic of 1907. Hoboken, NJ: Wiley and Sons.

Ferguson, N. (2017). The square and the town. London, UK: History's Hidden Networks.

Fisher, I. (1911). The purchasing power of money. New York, NY: Macmillan.

Gurley, J. G. (1960). Liquidity and financial institutions in postwar period. Study Paper (No. 14), Joint Economic Committee, Washington.

Gurley, J. G., \& Shaw, E. S. (1955). Financial aspects of economic development. The American Economic Review, 45(4), 515-538.

Gurley, J. G., \& Shaw, E. S. (1960). Money in a theory of finance. Washington, D.C.: Brookings Institution.

Hansen, A. (1953). A guide to Keynes. New York, NY: McGraw-Hill.

Kalecki, M. (1965). Theory of economic dynamics. Retrieved from http://www.levy.org/pubs/wp74.pdf

Levy, S. J., \& David, A. (1983). Profits and the future of American society. Retrieved from http://www.levy.org/pubs/wp74.pdf

Mackay, C. (1996). Extraordinary popular delusions and the madness of crowds. New York, NY: Harmony Books.

Marty, A. L. (1961). Gurley and Shaw on money in a theory of finance. Journal of Political Economy, 69(1), 56-62. Retrieved from http://www.jstor.org/stable/1829227

Minsky, P. H. (1992). The financial instability hypothesis. Working Papers (No. 74), Levy Economics Institute of Bard College. Retrieved from http://www.levyinstitute.org

Mundell, R. (1999). A reconsideration of the twentieth century. Retrieved from http://www.columbia.edu/ ram15/nobelLecture. html

Rueff, J. (1964). The age of inflation. Chicago: Regnery.

Rueff, J. (1971). The monetary sin of the west. New York, NY: MacMillan

Shiller, R. J. (2005). Irrational exuberance. Princeton, NJ: Princeton University Press.

Simmel, G. (1900; 2004). The philosophy of money. Lipzig, New York, NY: Routledge.

Triffin, R. (1961). The gold and the dollar crisis. New Haven: Yale University Press. 